\title{
Visual field analysis for night-time drivers
}

Abstract. The determination of observer's adaptation luminance based on luminance distribution in the observer's field of view and the adaptation of the human eye in a current question occupying lot of research teams worldwide. The impetus for the development of this matter is especially the need to determinate the adaptation luminance in order to calculate and determinate the adaptation performance (vision) in terms of mesopic vision.

The aim of this paper is not to accurately determine the process of vision adaptation, but to analyze the observer's field of view luminance distribution - especially of a driver at night. Measurements and luminance distribution evaluations of different types of roads and light situations were carried out with the goal to discuss this issue and discover how big the luminance differences are and to what situations of the surroundings the eye must adapt to during a ride.

Keywords: Visual field, field of view, luminance distribution

\section{Introduction}

In last ten years are themes about mesopic vision highly discussed even on highest level of $\mathrm{CIE}$ committed. For further progress in implanting mesopic theory, photometry and evaluation in practise, there are several unanswered questions. One of them is about of the visual adaptation. This is one of the essences of describing of visual performance for human eye. Without knowing "how adaptation works" even professionals or special scientists' teams over the word are not able to give satisfying answers how to evaluate different lighting situations in terms of road lighting.

This paper is dedicated to describe results of several measurements of distribution of luminance in the field of view in task of night-time driving.

Aim of the paper is not to precisely describe every possible street lighting situation in or out of towns. Aim is to examine typical lighting situations and help to focus next research.

\section{Preparing and measuring}

For measuring of distribution of luminance in the field of view for night-time drivers was used luminance digital camera with wide-fish-lens to help cover all possible direction of view of user. From the many possible ways for measuring of luminance were not chosen the typical way of measuring communication by Czech standards ČSN EN 13201 due to our requirements to measure all possible direction of look by communication user. Unfortunately requirements of ČSN would be met by using camera lens with long focal length, which do not fit for aim of research. However main predisposition were to accept influence of "in car position" for driver. This was done by installing camera to positon very similar to drivers itself on Fig.1.

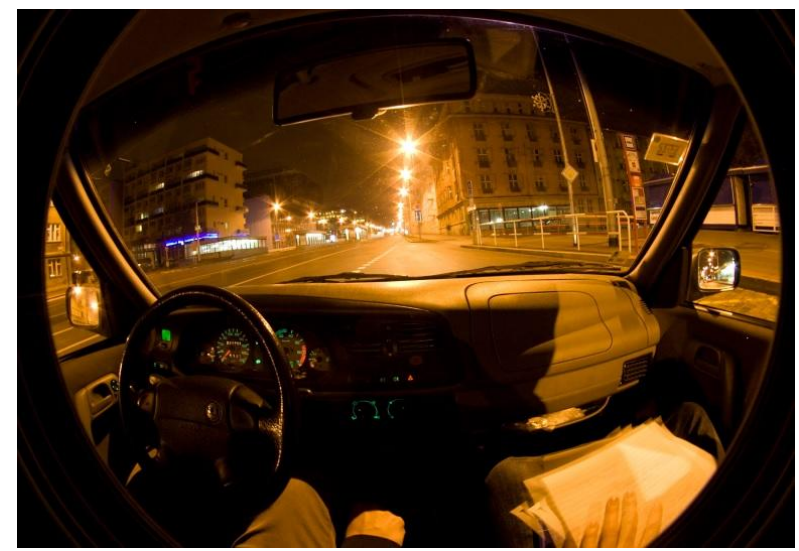

Fig.1. Set up photo - normal photography
Therefore camera was installed in to car in position, where important angles were covered. Position of camera was slightly close to the middle of the car - to covered as maximum outside look as possible. To gain high luminance range where taken 3 shots, each with different exposition set up. After processing the program we were able to complicate HDR (high dynamic range) picture as shown on Fig.2.

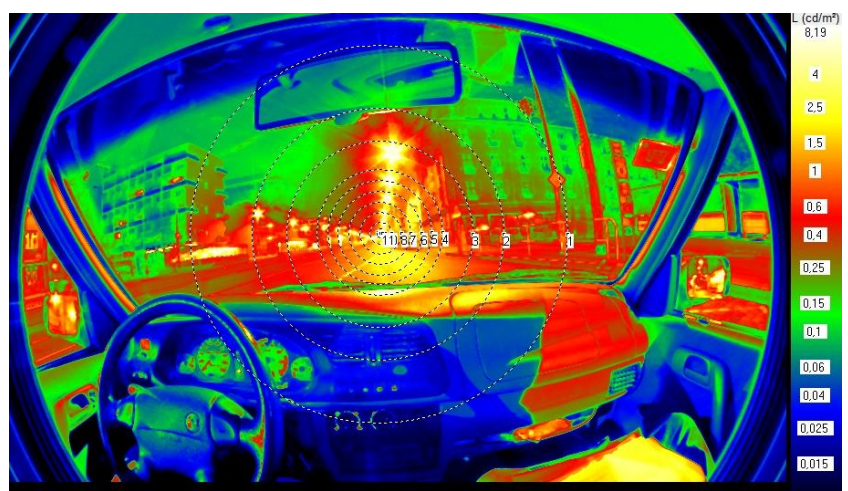

Fig.2. Picture for evaluation of distribution of luminance (Shutter time for HDR - 4 sec., $15 \mathrm{sec}$. and $30 \mathrm{sec}$.)

Luminance where evaluate for each circle area as shown on Fig.2, where each circle (1 to 10) matches to different and predefined angle of view $\left(1^{\circ}\right.$ to $\left.90^{\circ}\right)$. Results coming from this type of evaluating are presented in next chapter.

In most light-homogenise environment as is "interior zone" in tunnels, where is constant speed, where taken measurement in moving car to simulate natural work of the vision during driving. Picture from this measurement can be seen on Fig.3.

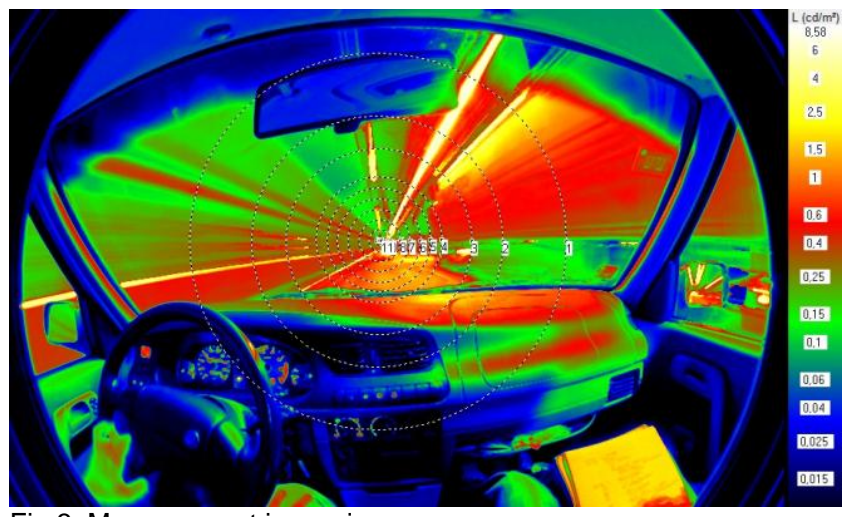

Fig.3. Measurement in moving car 


\section{Evaluation by circular area}

After taking a measurement where all shots post processed in evaluation program LMK2000. Individual road-scenes where divided to four groups by the luminance level and by environment itself.

Every group is evaluated in rage of vision angles $1^{\circ}$ to $90^{\circ}$ degrees. However, for section from $1^{\circ}$ to $10^{\circ}$ degrees results are highly inaccurate due to each evaluated scene was necessary to adjust middle point of direction of axis view for $1^{\circ}$ and with that all other circle areas. Need to move the middle of circles was cause by different landscape and shape of road. Even with this adjustment there were other issue. Differences between same angels (smaller than $10^{\circ}$ including) in various environments where almost about $350 \%$ of luminance different.

Group 1 represents low luminance level environments without the artificial street lighting. Sample of this type is shown on Fig. 4.

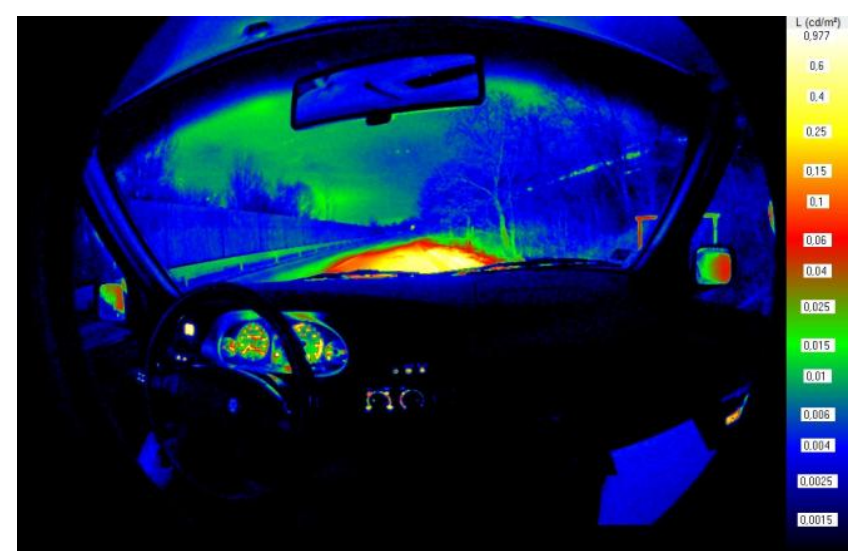

Fig.4. Group 1 environment sample

For Group 1 are typical feature like low luminance of car dashboard, large differences in luminance between illuminated area (road) and surroundings environment. Distribution of luminance across driver's visual field is shown on Fig.5.

Group 2 represents most of the road lighting situation in the town. Environment it's characterized by low speed traffic $(\max 50 \mathrm{~km} / \mathrm{h}$ ) with pedestrians and high density crossroads. Distribution of luminance across driver's visual field is also shown on Fig.5. For this situation are typical surrounding area made by pedestrians' sidewalks, low poles for street lighting luminaires, bushes and trees near to the road as also houses. Typical example of group 2 can by represented by Fig. 6 .

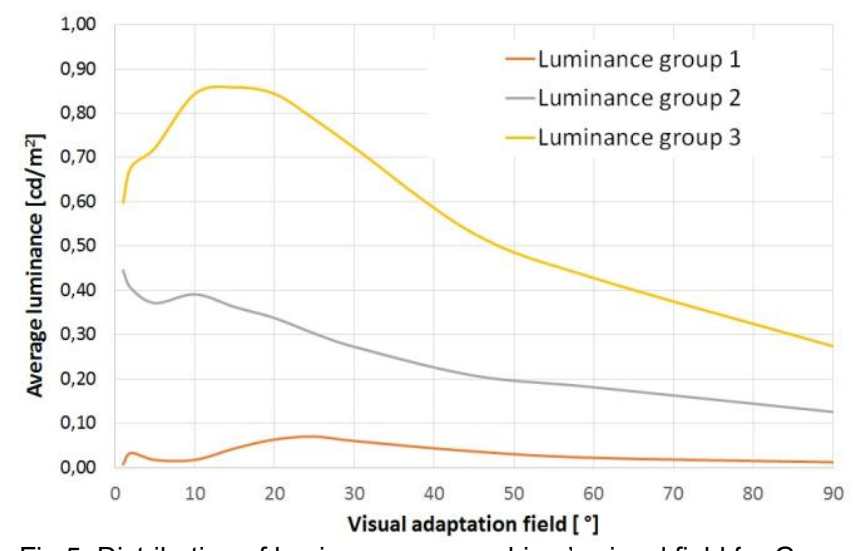

Fig.5. Distribution of luminance across driver's visual field for Group 1,2 and 3.

Group 3 is occupied by two different group of environment. First can be described as main traffic roads in town (maximum speed - usually $80 \mathrm{~km} / \mathrm{h}$, high ground walls around road or ani-sound barriers). Second subgroup is formed by roads on squares or plazas (large surroundings, sometime with artificial lighting and high walls of houses around). These two subgroups are different, but yet, by the measurement the distributions of luminance across visual field shows very similar results. For example it is low change of luminance between car dashboard and surroundings or comparatively small change between luminance of road and surrounding area. Distribution of luminance across driver's visual field is shown on Fig.5.

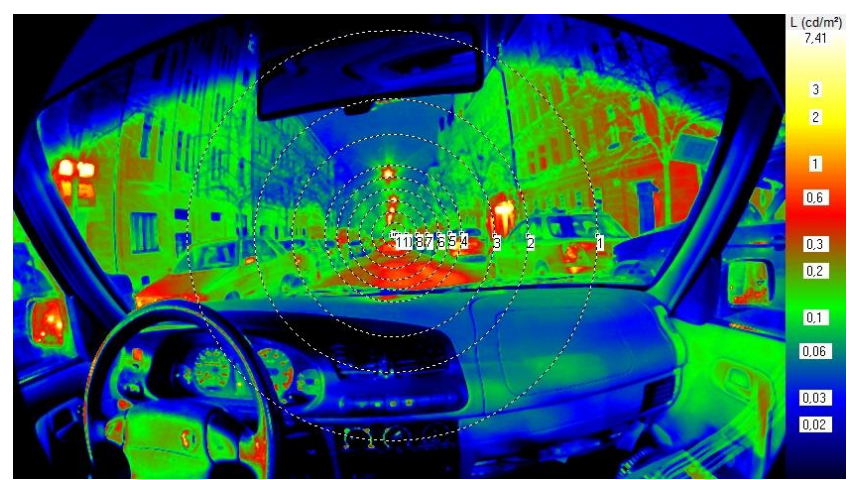

Fig.6. Group 2 environment sample

Group 4 collects special cases of lighting situations in town, where traffic intensity is high and it could be combined with high intensity of pedestrian and stops of public transports. Also it could be tunnels where luminance of walls is high thanks to small distance to luminaire and cars headlights. Those situations are represented on Fig.1 and Fig3. Distribution of luminance across driver's visual field is shown on Fig.7 with offer to compare it to other groups.

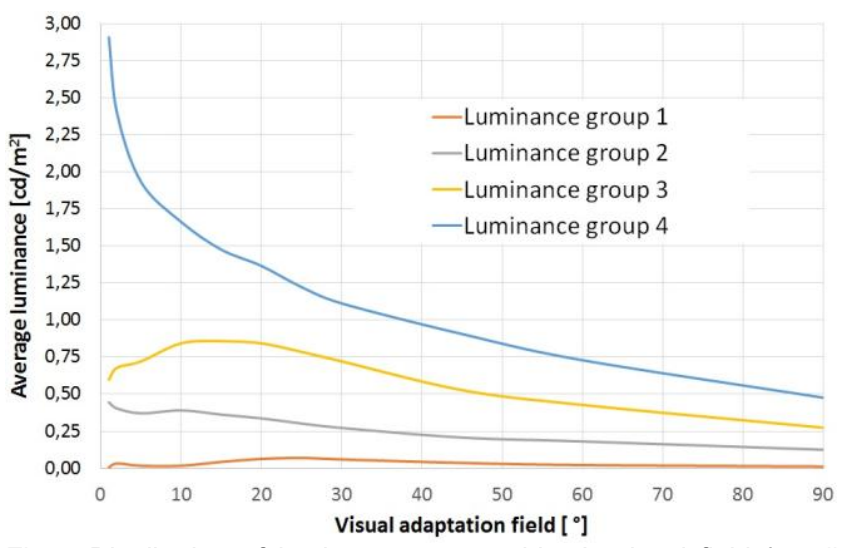

Fig.7. Distribution of luminance across driver's visual field for all four groups.

In every group can be observed decrease in average luminance value for wider visual field of observer and there is no clear answer for right way for measuring adaptation luminance or for question of wide of adaptation field of view.. Therefore there is still question about reviews and measuring adaptation area. Average luminance across area defined by circular area is not giving the answer for relationship between road and surroundings. It is necessary to use evaluation by divide areas.

\section{Evaluation by divide areas}

Different approach to evaluate distribution of luminance in field of view for night-time drivers is in splitting off 
the visual filed on two main areas. First have to be the road itself and second are surroundings. Comparison of these two locations could be express by using percentage value of average luminance of sides (behind of edges of road) related to average luminance value of road. Means the number of percentage give information about amount of luminance measured in surrounding area (environment-ground, trees, buildings and ets.) which are not located on the road directly.

The results of the division to two areas are evident in Table 1.

Table 1. Percentage value of average luminance of sides (behind of edges of road) related to average luminance value of road

\begin{tabular}{|c|c|}
\hline Place & Percentage [\%] \\
\hline $\begin{array}{c}\text { Country side } \\
\text { - without road lighting }\end{array}$ & 6 \\
\hline $\begin{array}{c}\text { Low intensity traffic places in town } \\
\text { - with road lighting }\end{array}$ & 58 \\
\hline $\begin{array}{c}\text { High intensity traffic places in town } \\
\text { - with road lighting }\end{array}$ & 76 \\
\hline $\begin{array}{c}\text { Average for town } \\
\text { - with road lighting }\end{array}$ & 65 \\
\hline
\end{tabular}

Each place in Table 1. is almost identical with naming and dividing of communications to "group 1 to 4" from pervious chapter. For evaluation by divide areas have to be used (at least for now), different names of groups due to technical reason of measuring and evaluating of results.

\section{Conclusion}

During this pilot project of measuring luminance distribution where find out several important facts. Many of them are very important for future work and research.

Those are fact like non-similar or comparable outcome in evaluation of average luminance for visual field of $1^{\circ}$ to $10^{\circ}$. This result clearly show, that there is no possible way for making standards to score eye adaptation only by onaxis vision due to measuring and technical limitations of standardized measurements. By the graphs on fig.7. could by, for future measuring, predicted more than $100 \%$ differences in average luminance for divergent size of field of view. However, there is strong tendency for most of the environmental (roads and surroundings areas) to have similar decrease waveform of average luminance across the visual field.

Another important finding was the possibility of splitting all communications if pre-defined work "Groups". Deeper evaluations of possibilities of splitting will be research. However, as shown by Table 1., there are new values of percentage of average luminance of surrounding area related to average luminance value of road. Those numbers could be used for evaluation of eye adaptation and used for proceed in mesopic vision evaluation.

\section{Acknowledgement}

Special thanks go to Bc. Davit Tomáš for being part of the team. Author is mostly thankful to colleagues from VŠB-TUO for supporting with ideas and equipment's.

This work was supported by the Grant Agency of the Czech Technical University in Prague, grant No. SGS13/197/OHK3/3T/13.
[1] T. Goodman, "Photometric Measurement using the $\mathrm{CIE}$ System for Mesopic Photometry," CIE Inroductory Tutorial on Mesopic Photometry, 2012

[2] J. Habel, P. Žák, J. Zálešák, "Determination of luminous flux in conditions of mesopic vision," Przeglad Elektrotechniczny, 2013, vol. 89, no. 06, p.20-24, ISSN 0033-2097.

[3] BAXANT, P.; ŠKODA, J. Digitální fotografie a její využití ve světelné technice. Světlo. 2010. 2010(1). p. 47 - 49. ISSNI 1212-0812.

[4] BAXANT, P.; ŠKODA, J. Digitální fotografie a její využití ve světelné technice - dokončení z čísla 1/2010. Světlo. 2010. 2010(2). p. 46 - 48. ISSN $1212-0812$.

Authors: ing. Jan Zálešák, ČESKÉ UČENÍ TECHNICKÉ V PRAZE, Katedra elektroenergetiky, Technická 216627 Praha 6, Czech Republic, e-mail: zalesja1@fel.cvut.cz

\section{REFERENCES}

